\title{
Condition of laboratory-reared and wild-caught larval Atlantic menhaden Brevoortia tyrannus as indicated by metabolic enzyme activities
}

\author{
Tristan J. Fiedler*, M. Elizabeth Clarke, Patrick J. Walsh** \\ Division of Marine Biology and Fisheries, Rosenstiel School of Marine and Atmospheric Science, University of Miami, \\ 4600 Rickenbacker Causeway, Miami, Florida 33149, USA
}

\begin{abstract}
As part of the South Atlantic Bight Recruitment Experiment (SABRE), the condition of larval Atlantic menhaden Brevoortia tyrannus from Onslow Bay, North Carolina, USA, was determined. The activities of the metabolic enzyme lactate dehydrogenase (LDH) were assayed in larval Atlantic menhaden to determine nutritional condition of laboratory-reared and wild-caught larvae on cruises in 1992 to 1994. In laboratory calibrations, larvae whose first feeding was delayed had depressions in protein-specific LDH activities, and LDH activity appeared to scale with length. Wild larvae had LDH activities within the range of activities found in laboratory-reared larvae and were classified into 3 nutritional categories based on length and LDH activities. Fewer than $30 \%$ of larvae collected from the majority of stations were classified in superior condition. No differences were detected between larvae collected during the day and those collected at night. Significant decreases in condition were evident with increasing distance from the Gulf Stream Front. LDH activities indicated that a substantial percentage of wild-caught menhaden larvae were poorly nourished during the period examined.
\end{abstract}

KEY WORDS: Larval menhaden · Lactate dehydrogenase $\cdot$ Nutritional condition · Onslow Bay

\section{INTRODUCTION}

The major natural cause of population fluctuations observed in marine fish stocks is interannual variability in recruitment success. Subtle changes in mortality rates, whether due to predation or starvation episodes during early life history stages, may play a significant role in subsequent recruitment variability (Harding 1974, Cushing 1983, Hunter 1984, Bailey \& Houde 1989). Seemingly minor shifts in growth rates, stage duration, and survivorship may generate effects several orders of magnitude greater upon recruitment success into the adult population (Houde 1987).

Food assimilation rates, energy budgets, and behavioral aspects of feeding have also been extensively

\footnotetext{
- Present address: Graduate Program in Biochemistry, Cell and Molecular Biology, University of Miami School of Medicine, R-629, PO Box 016129, Miami, Florida 33101-6129, USA •-E-mail: pwalsh@rsmas.miami.edu
}

studied in order to gain insight into survival parameters for marine fish larvae (Blaxter \& Ehrlich 1974, Laurence 1977, Houde \& Schekter 1980, Cetta \& Capuzzo 1982, Kentouri \& Divanach 1982, Frank \& Leggett 1985). The interactions between food availability and other biotic factors, such as predation (e.g. through decreased predator avoidance capabilities of poorly nourished larvae) or competition, are complex. Larval fish and egg populations are highly aggregated, both spatially and temporally (Laurence 1974, Hunter 1981). Fine spatial scale patchiness from meters to tens of meters may be of importance to larval fish because it corresponds to the effective environment ('ambit') of zooplankters which is defined by their limited swimming ability (Wiebe 1970, Haury et al. 1978, Haury \& Wiebe 1982, Davis et al. 1992).

Many techniques have been utilized to determine the nutritional status of larval fish in the context of estimating starvation-induced mortality. Traditional approaches, however, preclude the shipboard analyses 
of large numbers of samples necessary to construct near real-time synoptic field maps of nutritional condition. Furthermore, in many cases these techniques have been time consuming, and large numbers of analyses could not be performed easily (Theilacker 1980, 1986, Hay 1981, 1982, Jennings 1991, Hjorleifsson \& Klein-MacPhee 1992). Clarke \& Walsh (1993) and Clarke et al. (1992) have used metabolic enzyme activities to characterize the condition of zooplankton during laboratory experiments and suggest that these methods may be useful in analyzing field-caught specimens. These investigations were based on the welldocumented effects of feeding on the activities of juvenile and adult fish enzymes (Moon 1983, Lowery et al. 1987, Lowery \& Somero 1990, Yang \& Somero 1993).

Atlantic menhaden Brevoortia tyrannus is a highly abundant and economically important fish species. It also comprises the forage base for many pelagic game fish inhabiting the Western North Atlantic (Reintjes \& Keney 1975, Ahrenholz et al. 1987, Smith et al. 1987). The Atlantic menhaden is an estuarine-dependent clupeid species whose egg and larval stages occur offshore, on the continental shelf. Transport of pelagic stages is predominantly westward across the shelf, affecting eggs and larvae of up to approximately $15 \mathrm{~mm}$ standard length. Larvae are planktonic for at least $1 \mathrm{mo}$, possibly up to $3 \mathrm{mo}$, from time of hatching. Late-larval stages and juveniles between 15 and $20 \mathrm{~mm}$ (standard length) immigrate through coastal inlets and subsequent development occurs in estuarine habitats (Ahrenholz 1991). Flexion occurs between 8 and $10 \mathrm{~mm}$, and transformation into juveniles occurs at approximately $30 \mathrm{~mm}$ after estuarine immigration. Cross-shelf movement of $B$. tyrannus larvae results from interactions between nearshore, vertical, and estuarine circulation (Lewis \& Wilkens 1971, Fore \& Baxter 1972, Pietrafesa \& Janowitz 1988, Hoss et al. 1989). During this cross-shelf transport, the larvae face a myriad of conditions and food availabilities. Therefore, in this study we use metabolic enzyme activities calibrated in laboratory experiments to characterize the condition of field-caught menhaden larvae during this cross-shelf transport.

\section{METHODS}

Sample preservation and biochemical methods. Cod-ends were quickly removed from plankton nets following short-duration tows (5 to $10 \mathrm{~min}$ ) and emptied into ice-cold seawater (maintained at approximately 2 to $3^{\circ} \mathrm{C}$ by previously frozen gel-packs). Larvae were quickly sorted from the sample and standard lengths measured. The tail was removed from the head and gut, briefly rinsed in chilled $280 \mathrm{mM}$ sucrose, $10 \mathrm{mM}$ sodium HEPES ( $\mathrm{N}$-[2-hydroxyethyl]piperazine-
$\mathrm{N}^{\prime}$-\{2-ethanesulfonic acid]\}, $\mathrm{pH} 8.0$ and frozen in liquid nitrogen. Ice-cold $50 \mathrm{mM}$ sodium-HEPES buffer $\mathrm{pH} 7.5$ was added for tissue sonication (Kontes Ultra-Sonic Cell Disrupter) followed by centrifugation at $13000 \times 9$ for $20 \mathrm{~s}$ (Eppendorf Model 5415C Microcentrifuge). Crude supernatants were used directly for lactate dehydrogenase activity assays according to methods of Clarke et al. (1992). In our prior studies on larvae, and others on adults, 2 enzymes showed particular utility in assessing condition, namely citrate synthase (a Kreb's cycle enzyme involved in aerobic catabolism) and lactate dehydrogenase $\left(\mathrm{LDH}_{i}\right.$ the terminal step of anaerobic glycolysis, a particularly important pathway for larval fish burst locomotion, Kaupp \& Somero 1989). Preliminary investigation (Fiedler 1994) indicated that LDH was most suitable for application to larval menhaden due to its high activity even early in development, and thus it was chosen for this study. Total soluble protein was measured in the same homogenates by a modification of the Lowry et al. (1951) method using bovine serum albumin (BSA) as a standard. LDH activities (picomole product produced per minute) were normalized to microgram ( $\mu \mathrm{g})$ protein from this method (i.e. protein-specific LDH activity).

Delayed feeding experiment. Laboratory eggs of Brevoortia tyrannus were obtained from W. F. Hettler, National Marine Fisheries Service, Beaufort Laboratory (Beaufort, NC) on 4 April 1992. Larvae were reared at the Rosenstiel School of Marine and Atmospheric Science on Virginia Key, Florida. Air temperature was maintained at $20 \pm 0.5^{\circ} \mathrm{C}$ with room air conditioners; tank water temperature was measured daily and remained between 18.5 and $20.0^{\circ} \mathrm{C}$. A photoperiod of $12 \mathrm{~h}$ light: $12 \mathrm{~h}$ dark was provided with fluorescent lights and timers. Salinity was also measured daily with an optical refractometer and fluctuated between 36 and 36.5 ppt. Equal volumes (3.6 l) of B. tyrannus eggs from a single spawning on 3 April 1992 were added to each of six $380 \mathrm{l}$ tanks on 4 April 1992 at an approximate density of 10 to 15 eggs $\mathrm{I}^{-1}$. Food densities were maintained at 2 wild copepod nauplii $\mathrm{ml}^{-1}+2$ cultured rotifers Brachionus plicatilis $\mathrm{ml}^{-1} \operatorname{tank}^{-1}$, based on previous studies in our laboratory (Clarke et al. 1992). The wild nauplii were obtained during ebb and flood tides from the RSMAS dock in Bear Cut, Biscayne Bay, by short duration tows ( $<10 \mathrm{~min}$ ) with a 53 um mesh net, quantified, and added to the tanks until final concentrations were as stated. Ammonia accumulation in the closed system was minimized and zooplankton maintained by the daily addition of 11 of Isochrysis galbani (Tahitian strain). Tank bottoms were siphoned to remove accumulated debris as necessary. There were 6 experimental treatments corresponding to the time at which food was first presented to the fish (hatching day and 1, 3, 4, 5 and $6 \mathrm{~d}$ after hatching; 
DAH). Food intake was verified by visual inspection of the gut. Five individual larvae per tank were sampled each day. Larvae were then dissected, cryopreserved and analyzed as above.

LDH stability in net simulation. Larvae collected in the wild by towed plankton nets spend several minutes at ambient temperatures following expiration, before being cryopreserved. A simulated flow-through plankton net was constructed to test for any effects of net capture. Air temperature was maintained at $20 \pm 0.5^{\circ} \mathrm{C}$ for the duration. Ambient seawater temperature was $19.5^{\circ} \mathrm{C}$. Ten individual Brevoortia tyrannus larvae (14 DAH) were placed in a cone of $202 \mu \mathrm{m}$ mesh netting affixed to a cylindrical PVC pipe. Larvae were then subject to running seawater for discrete time periods of $10,15,20,25$, and $30 \mathrm{~min}$, then dissected, cryopreserved and analyzed as described above.

Field collections. As part of the SABRE program, Atlantic menhaden larvae were collected in Onslow Bay, North Carolina, during the winter spawning months of 1992, 1993, and 1994. Cruise dates, quantity of individual larvae obtained, and number of stations sampled are described in the appropriate figure legends. Larvae were collected by surface (area of greatest menhaden abundance) plankton tows with a $60 \mathrm{~cm}$ diameter $333 \mu \mathrm{m}$ mesh paired bongo net. Sampling was conducted both in the daytime and at night, whenever the ship arrived at a station. Fluorescence measurements taken during Cruise 3 were converted into chlorophyll a (chl a) concentration $\left(\mu \mathrm{g} \mathrm{l}^{-1}\right)$ by calibration of standards performed by the National Marine Fisheries Service (NOAA) Beaufort Laboratory, NC.

\section{RESULTS}

\section{Delayed feeding experiment for Brevoortia tyrannus larvae}

No significant differences (ANOVA, p > 0.05) in LDH activity were found between treatments on DAH (days after hatch) 1 through 4 , although there was a significant increase on $1 \mathrm{DAH}$ (Fig. 1). However, larvae began to exhibit significant increases in LDH activity within $2 \mathrm{~d}$ following first feeding. Larvae fed on the day of hatch exhibited significantly elevated proteinspecific LDH activities compared to all other treatment groups on all sampling days following $4 \mathrm{~d}$ post-hatch (ANOVA, $p<0.05$ ). Intermediate LDH activities were observed for the group of larvae fed on $3 \mathrm{DAH}$. This treatment group exhibited enzyme activities significantly less than the 0 DAH group and significantly greater than the 6 DAH treatment (ANOVA, SNK, $\mathrm{p}<0.01$ ) for all sampling periods following $4 \mathrm{~d}$ posthatching.
The fish which were fed on 6 DAH had significantly lower activities than all other groups following $4 \mathrm{~d}$ post-hatch. For the purpose of developing a laboratory calibration to relate enzyme activity and feeding in field caught larvae, 3 representative treatment groups (first fed on 0 and $1 \mathrm{DAH}, 3$ and $4 \mathrm{DAH}$, and 5 and 6 $\mathrm{DAH}$ ) were selected since the entire range of data values were represented. Regression analysis (ANCOVA, $p<0.05)$ found significant differences in the increase in $\mathrm{LDH}$ activities among these 3 treatments, but not consistently between treatments differing by only $1 \mathrm{~d}$.

Growth rates in terms of length were similar for all treatment groups (Fig. 2), excepting those individuals starved until 5 and $6 \mathrm{DAH}$. The $5 \mathrm{DAH}$ treatment exhibited intermediate growth rates lower than the 4 groups fed earlier but slightly higher rates than the group fed on $6 \mathrm{DAH}$. The $6 \mathrm{DAH}$ treatment group exhibited a significant decrease in mean length for the 3 sampling periods following $3 \mathrm{~d}$ post-hatching, possibly due to enhanced mortality in these older larvae, which require more food. Consequently, a disproportionate amount of smaller size-class individuals may have been sampled. Growth parameters for all treatment groups are given in Table 1.



Fig. 1. Delayed feeding effects on LDH activity 


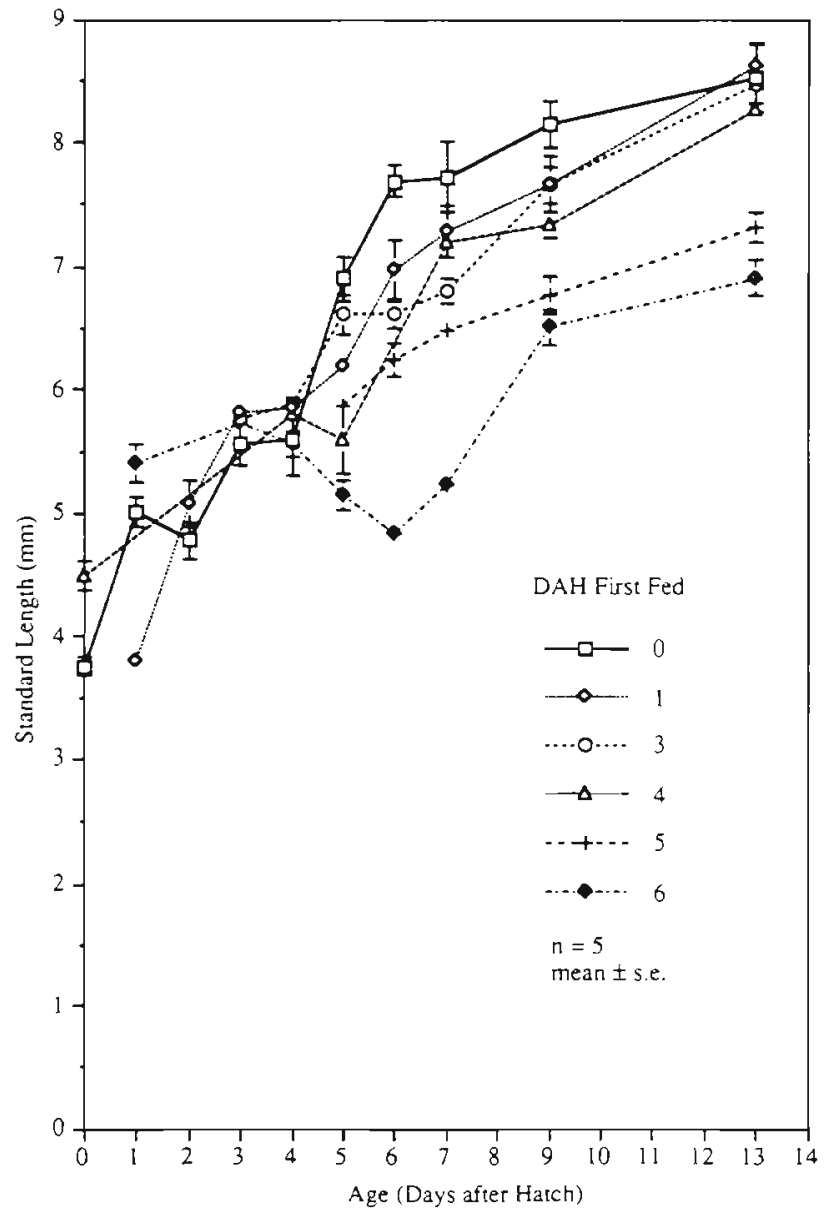

Fig. 2. Delayed feeding effects on standard length

The observed growth rates in Brevoortia tyrannus based on standard length (Fig. 2, Table 1) were curvilinear, and, therefore, an exponential model natural logarithmic transformation of the ordinate was necessary to linearize the data. All ln-transformed data produced highly significant non-zero linear regressions (ANOVA, $p<0.001$ ). Approximately $16 \%$ more of the variation was explained by the logarithmic equations than by the initial linear model. Groups fed on day of hatching and 1 DAH had significantly higher growth rates than all other groups. The 2 lowest growth rates were observed in those tanks fed on 5 and 6 DAH, evidenced by the lowest

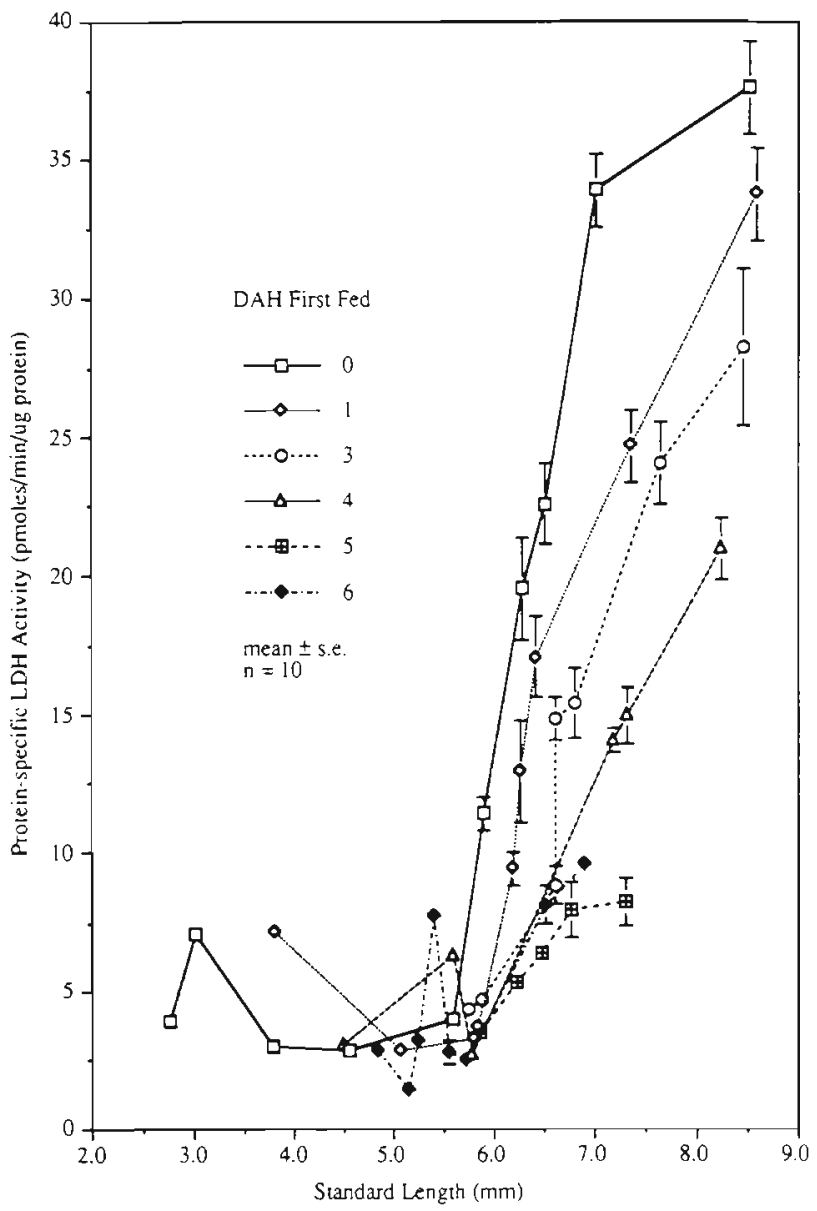

Fig. 3. Delayed feeding effects on LDH activity versus length

slopes. These 2 treatments had insignificant slope differences from each other ( $t$-test, df $=63, p=0.24)$. Groups fed on 3 and $4 \mathrm{DAH}$ had slopes below those fed earlier, but significantly greater than tanks fed on 5 and 6 DAH ( $t$-test, $\mathrm{df}=98, \mathrm{p}<0.05)$. In summary, in addition to the observation of 3 groups of LDH activities, 3 groups of significantly different growth rates based on standard length increases were observed: fish first fed on $0-1,3-4$, and 5-6 DAH (see Table 1, note slopes for each treatment).

When analyzed on a per length basis, proteinspecific LDH activities demonstrated a strong increase (Fig. 3) versus standard length. Highly significant non-

Table 1. Brevoortia tyrannus. Growth rate parameter variation.

\begin{tabular}{|c|c|c|c|c|c|c|c|c|c|}
\hline & \multicolumn{6}{|c|}{ Day after hatch first fed } & \multicolumn{3}{|c|}{ Group } \\
\hline & 0 & 1 & 3 & 4 & 5 & 6 & $0 / 1$ & $3 / 4$ & $5 / 6$ \\
\hline SL increase (mm) & 4.7 & 4.8 & 4.7 & 4.5 & 3.6 & 3.2 & 4.81 & 4.60 & 3.36 \\
\hline Slope for $\ln Y$ & 0.053 & 0.051 & 0.034 & & 0.022 & 0.018 & 0.052 & 0.038 & 0.020 \\
\hline $\mathrm{R}^{2}(\ln Y)$ & 0.826 & 0.838 & 0.957 & 0.929 & 0.945 & 0.437 & 0.613 & 0.778 & 0.841 \\
\hline$Y$-intercept $\ln Y$ & 1.707 & 1.696 & 1.822 & 1.731 & 1.840 & 1.785 & 1.702 & 1.776 & 1.812 \\
\hline
\end{tabular}


zero slopes (ANOVA, $p<0.05$ ) were found for all groups, indicating an increase in anaerobic potential with size throughout this developmental period. Larvae first fed on the day of hatch had significantly greater changes in protein-specific LDH activity ( $t$-test, $\mathrm{df}=98, \mathrm{p}<0.05$ ) than all other treatment groups. LDH activity was inversely correlated with the time between hatching and first feeding. Parameters for regression analyses are given in Table 2 . Treatment groups did not show any significant differences until $5.6 \mathrm{~mm}$ standard length and then exhibited linear increases as demonstrated by highly significant $F$ values (ANOVA) and large correlation coefficients

In summary, protein-specific LDH activities and growth rates are significantly affected by the timing of first feeding in Brevoortia tyrannus larvae, and highly significant nutritional effects upon LDH activities are seen both as a function of age and standard length (after $6 \mathrm{~mm}$ ). During the course of the $14 \mathrm{~d}$ experiment, LDH activities increased nearly 10 -fold, a broad envelope for field values to fall into.

\section{LDH stability in net retention simulation}

No significant differences in protein-specific LDH (ANOVA, $F=1.4142, \mathrm{p}=0.221$ ) levels were found during simulated plankton net experiments up to $30 \mathrm{~min}$ in duration (Table 3).

\section{Field-collected larvae in Onslow Bay, NC}

Wild Atlantic menhaden larvae were collected in conjunction with the SEFC Beaufort Laboratory, in Onslow Bay, North Carolina (76.4-77.8 W, 33.8-34.6 ${ }^{\circ} \mathrm{N}$ ), during the winter spawning months of 1992,1993 , and 1994. Stations (Fig. 4) are identified by cruise year followed by station number (e.g. 9308). The 2 stations sampled on Cruise 4 (February 1994) have been designated 94258 and 94259 to distinguish them from January 1994 stations. No significant differences were found in the numbers of larvae collected per station among all 4 cruises (Welch ANOVA, $F=1.1761, \mathrm{p}=$ 0.3885 ), but the large sampling variability and difference in number of samples obtained would in any case virtually preclude any statistically rigorous intercruise comparison (Table 4). Cruises 1, 2, and 3 encompass $95.3 \%$ of the field collections since only 2 stations were sampled on Cruise 4.

Larvae collected from Cruises 2 and 3 were significantly longer $(7.5 \pm 0.1$ and $7.4 \pm 0.1 \mathrm{~mm}$ ) than on cruises 1
Table 2. Protein-specific LDH activity versus length in delayed feeding experiment

\begin{tabular}{|crrll|}
\hline DAH fed & Slope $\pm \mathrm{SE}$ & Fratio & prob. $>F$ & \multicolumn{1}{c|}{$\mathrm{R}^{2}$} \\
\hline 0 & $11.23 \pm 2.49$ & 20.306 & 0.0108 & 0.835 \\
1 & $9.95 \pm 1.12$ & 77.778 & 0.001 & 0.928 \\
3 & $9.44 \pm 0.99$ & 90.329 & 0.002 & 0.947 \\
4 & $6.32 \pm 0.89$ & 49.447 & 0.0059 & 0.943 \\
5 & $3.51 \pm 1.15$ & 9.226 & 0.0229 & 0.605 \\
6 & $3.39 \pm 0.65$ & 26.647 & 0.0141 & 0.899 \\
\hline
\end{tabular}

Table 3. Mean protein-specific activities for net retention test

\begin{tabular}{|rcc|}
\hline Min & $\mathrm{n}$ & LDH activity (mean $\pm \mathrm{SE}$ ) \\
\hline 5 & 10 & $45.659 \pm 8.304$ \\
10 & 10 & $38.164 \pm 7.289$ \\
15 & 10 & $44.947 \pm 6.062$ \\
20 & 10 & $44.855 \pm 7.168$ \\
25 & 10 & $49.565 \pm 6.213$ \\
30 & 20 & $42.971 \pm 3.006$ \\
\hline
\end{tabular}

and $4(7.1 \pm 0.1$ and $7.0 \pm 0.1 \mathrm{~mm}$, Welch ANOVA, $F=$ 13.639, $p=0.001$; Tukey-Kramer HSD). The range of mean standard lengths was however comparatively small, only 6.7 to $7.9 \mathrm{~mm}$. The mean standard length per station for all cruises was between 6.7 and $7.9 \mathrm{~mm}$ with the exception of Stn 9301 in which the mean standard length (9.5 mm [n = 4]) was significantly greater (ANOVA, $\mathrm{p}<0.003, F=23.658$ ). No statistical relationship was detected between standard deviation of mean length per station and numbers of fish collected per station using all data (ANOVA, $F=0.8902, p=0.317, r^{2}$ $=0.02$ ). When only stations with 4 or more larvae were included ( $61 \%$ of field stations) a significant negative linear relationship was seen between length variability and abundance per station (ANOVA, $F=18.0140, p=$ $\left.0.003, r^{2}=0.44\right)$. Those stations at which the greatest numbers of larvae were collected (Stn 9212: $n=33$; Stn 9213: $n=29$ ) were most homogeneous. On the other hand, there was no statistically significant relationship between size, as measured by standard length, and abundance at stations of $n>3$ (ANOVA, $F=0.0484, \mathrm{p}=0.827, \mathrm{r}^{2}=0.001$ ).

Table 4. Mean number of larvae per station

\begin{tabular}{|llcrrr|}
\hline Cruise & Cruise ID & Cruise dates & n & $\begin{array}{r}\text { No. of } \\
\text { stations }\end{array}$ & $\begin{array}{r}\text { Larvae per } \\
\text { station }\end{array}$ \\
\hline 1 & AL-92-12 & 16-20 Dec 1992 & 112 & 14 & 8.0 \\
2 & AL-93-01 & 8-15 Jan 1993 & 102 & 17 & 6.0 \\
3 & OII-93-08 leg 2 & 11-20 Jan 1994 & 88 & 8 & 11.0 \\
4 & OII-93-08 leg 5 & 3-6 Feb 1994 & 15 & 2 & 7.5 \\
\hline
\end{tabular}



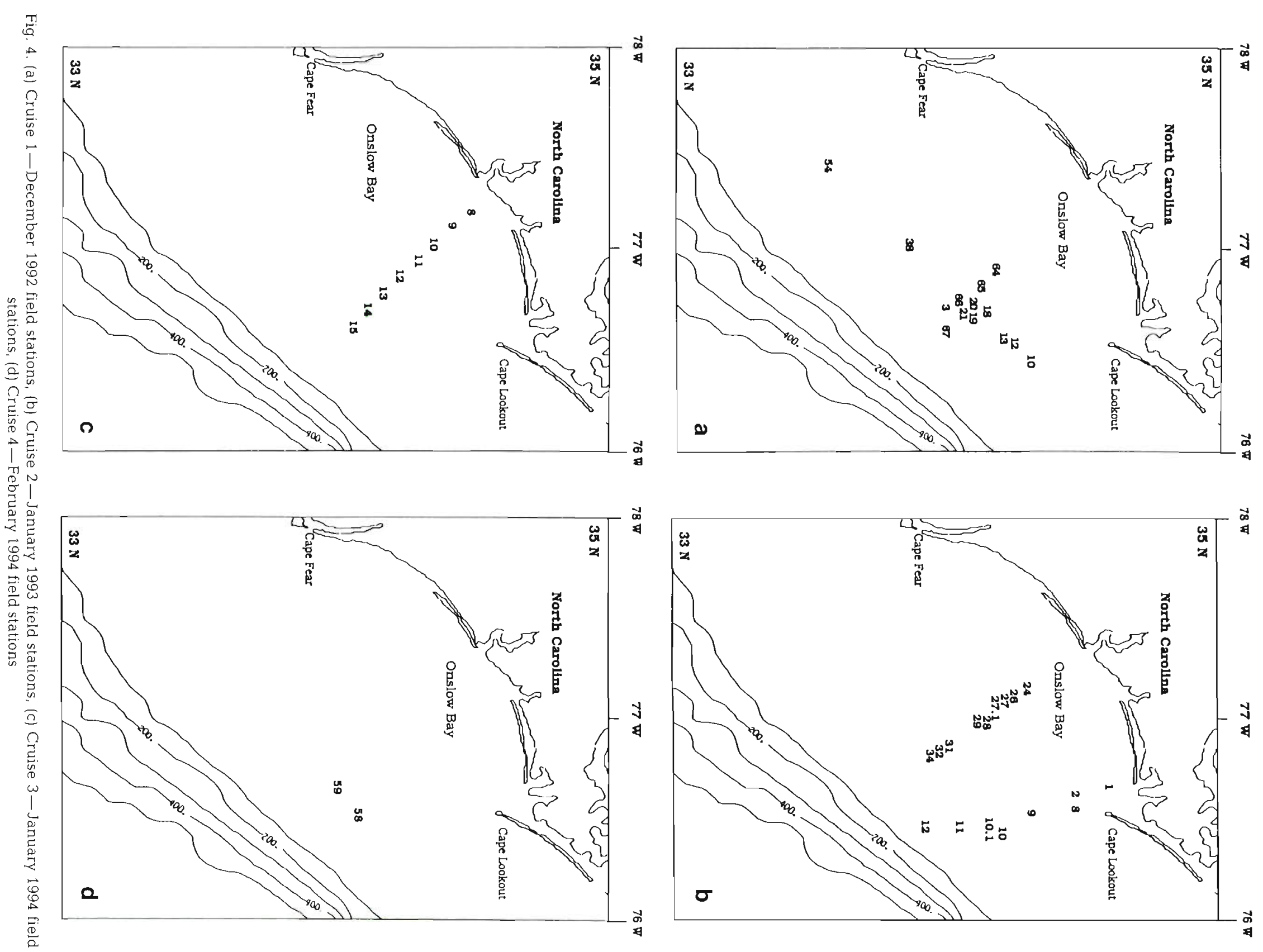
Atlantic menhaden larvae collected from all 4 cruises demonstrated a highly significant linear correlation (ANOVA, $F=704.98, \mathrm{p}<0.001, \mathrm{r}^{2}=0.68$ ) between standard length and total protein content per larva (Fig. 5). This fit to the data was better than other relationships tested, including curvilinear plots. Notably this relationship was the same for laboratory-reared larvae, suggesting that it would be reasonable to normalize enzymatic activities to protein content to account for larval size differences.

A total of 317 individuals were assayed from 4 field cruises representing 41 different stations. Enzyme activities were normalized to total protein content as discussed above to account for size differences and to make them comparable to activities for laboratoryreared larvae. Although there were no replicate determinations on single individuals, reproducibilities of both enzymatic activity and total body protein determination is approximately $\pm 5 \%$ (unpubl. data, Fiedler 1994). These differences are small compared to the variation in the data. Significant differences were found in protein-specific LDH (ANOVA, $F=4.5828$, $p=0.001$ ) activities among field stations (Fig. 6). Significant differences also exist between cruises with respect to $\mathrm{LDH}$ activity with Cruise 4 larvae $(\mathrm{n}=15)$ having the lowest mean activities (ANOVA, $F=8.868$, $p=0.001$, Tukey-Kramer HSD). Among the first 3 cruises, Cruise 3 activities were significantly greater than Cruise 1. Enzyme activities in field-collected larvae had values comparable to those determined

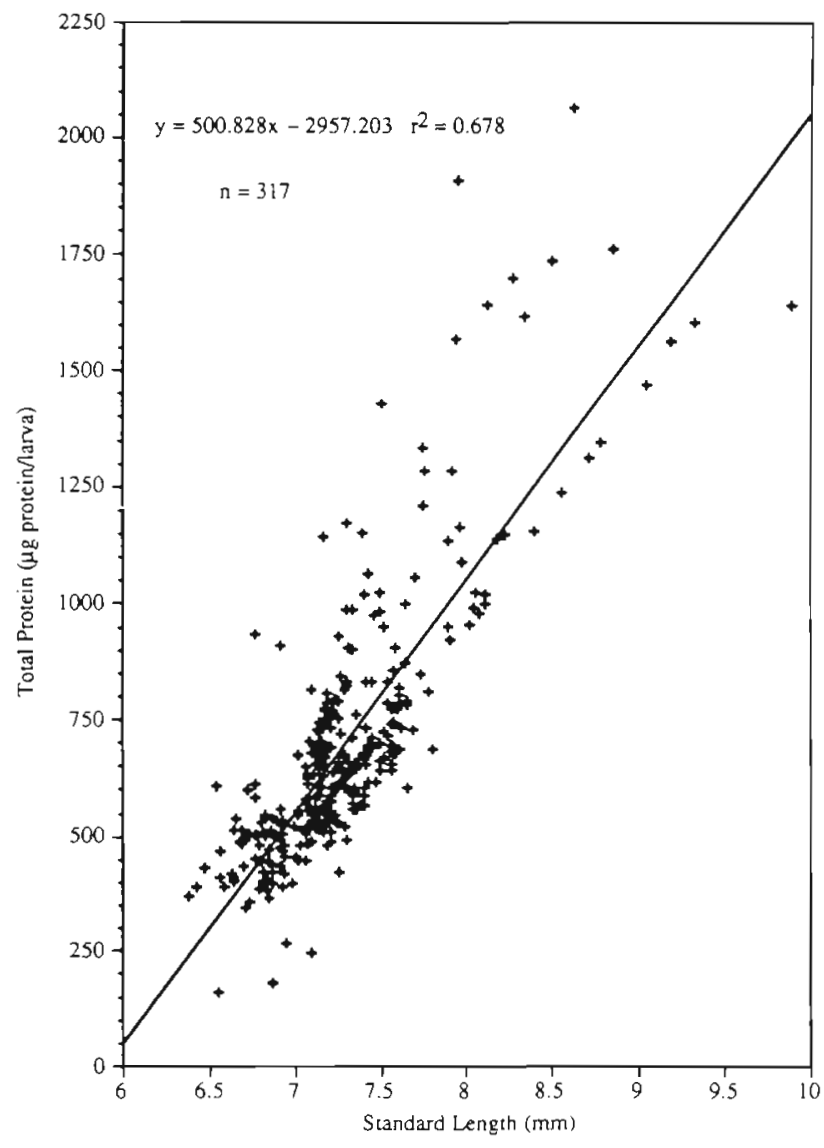

Fig. 5. Total protein versus standard length in field-caught larvae

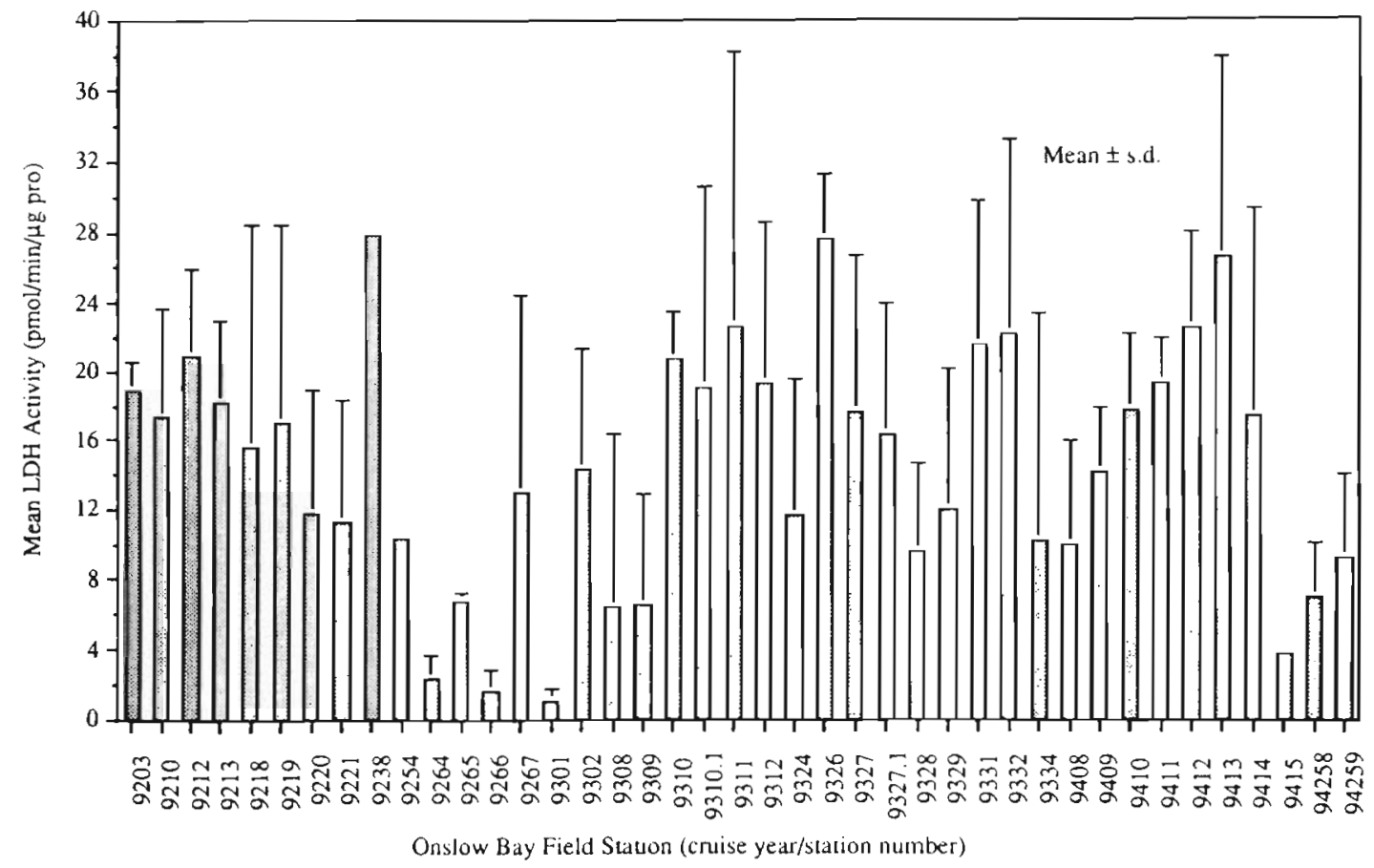

Fig. 6. Protein-specific LDH activity for field stations in Onslow Bay, NC, USA 
from laboratory-reared larvae in the delayed feeding experiment. Stations with fewer than 3 larvae were omitted from station analyses, but included in all individual-based analyses. LDH activities exhibited a greater range in the field data than in the laboratory experiments. No significant correlation was detected between standard length and protein-specific LDH activity (ANOVA, $F=0.1971, \mathrm{p}=0.6574, \mathrm{r}^{2}=0.006$ ). Out of 317 larvae collected, $218(68.8 \%)$ were gathered during daylight hours. No significant differences were found between day and night collections when analyzed with respect to standard length (ANOVA, $F=$ $0.040, p=0.8415)$ or protein-specific LDH activity (ANOVA, $F=0.001, p=0.971$ ). Mean values for these measurements were extremely close for day and night calculations.

\section{Field condition analyses}

LDH values seen in wild-caught larvae were compared to LDH for laboratory-reared larvae to assess nutritional condition (Figs. $3 \& 6$ ). Larvae were placed in 1 of 3 somewhat arbitrary nutritional conditions by normalizing their protein-specific LDH activity to their standard length as follows. Fish with activities above the lower $95 \%$ confidence interval (Cl) about the linear regression describing the treatment fed on $1 \mathrm{DAH}$, including the day of hatch treatment, were classified as 'healthy'. Larvae which were below the lower 95\% CI for the 1 DAH group (worse condition than fed on $1 \mathrm{DAH}$ ) but above the lower $95 \% \mathrm{CI}$ for the $4 \mathrm{DAH}$ treatment exhibit the condition of fish fed on 2, 3, or $4 \mathrm{DAH}$ and were classified as 'average' Wild-caught larvae with activities below the lower $95 \% \mathrm{CI}$ for the $4 \mathrm{DAH}$ treatment (representing the $5 \mathrm{DAH}$ treatment or below) were classified as 'starving' These were poorly fed individuals similar to those fed on 5 or 6 DAH. During Cruise 4 only 2 samples were obtained. These had insignificant differences in nutritional condition distribution (chi-squared, $\chi^{2}=0.096, p=0.7565$ ). Both sites had a majority of starved larvae $189 \%$ for Stn 94258, $83 \%$ for Stn 94259) and lacked any healthy individuals

\section{Cruise 1 - physical features and larval condition}

Cruise 1 occurred between 18 and 20 December 1992 in Onslow Bay (Figs. 4a \& 7a). The satellite data show a large filament of warm water $\left(21\right.$ to $\left.23^{\circ} \mathrm{C}\right)$ extending from Raleigh Bay into Onslow Bay, which had developed from an onshore meander of the Gulf Stream offshore of Cape Hatteras. It was subsequently entrained into a trailing frontal eddy whose core was located off Raleigh Bay. A strong frontal gradient was seen due to this filament in Raleigh Bay between Cape Lookout and Cape Hatteras. Between Cape Lookout and Cape Fear, however, the Gulf Stream Front was more highly dispersed, generating a broad temperature gradient (14 to $23^{\circ} \mathrm{C}$ ) across horizontal distances of approximately $40 \mathrm{~km}$. One small-scale feature occurred approximately $30 \mathrm{~km}$ south of Cape Lookout in which a meander of the western edge of the filament generated a southward intrusion of cold shelf water into the warmer mixed region, producing a strong east-west frontal boundary.

Larval condition was estimated at each of 14 stations composing 2 transects (Fig. 8a, b). Continuous temperature profiles for both transects were taken and were used to accurately locate frontal regimes. Salinity measurements varied minimally ( 36.10 to $36.40 \mathrm{ppt}$ ) and added little additional insight (as compared with temperature or, where available, fluorescence) as to the origin of specific water masses. This is not unexpected during the winter season ( $\mathrm{T}$. Lee pers. comm.).

The $32.7 \mathrm{~km}$ transect of Cruise 1 , running northeastsouthwest, consisted of 5 stations of 4 or more larvae. Significant differences in the distribution (chi-squared, $\chi^{2}=24.137, p<0.01$ ) of nutritional conditions were observed (Fig. 8a) across stations. The general pattern suggested better feeding conditions toward the northern extent of the transect near Cape Lookout as evidenced by a comparatively large percentage of nonstarving larvae at Stns 10 to 13 . Fewer than $25 \%$ of the fish collected at the 3 northeastern stations exhibited enzyme activities within the 'starved' grouping. The northeastern stations 9210,9212 , and 9213 occurred in the near vicinity but a few kilometers shoreward of the frontal boundary produced by the warm filament. If this front were the leading edge of a convex meander structure, convergence might be expected. Samples from this region of convergence also exhibited extremely high percentages of non-starving larvae $(81,97$, and $93 \%$, respectively). Stns 9218,9219, and 9220 were located $6.2 \mathrm{~km}$ to the seaward side of the strong east-west front directly south of Cape Hatteras. Larvae collected from this offshore zone were in comparatively poor nutritional condition with over $60 \%$ starving and no 'average' individuals at any of these stations.

A second transect perpendicular to the first also was sampled in Cruise 1 running $26.4 \mathrm{~km}$ northwestsoutheast (Fig. 8b). Statistical evaluation of the nutritional condition distributions indicated no significant differences among stations (chi-squared, $\chi^{2}=5.791$, $\mathrm{p}=0.44$ ) with continuous temperature records indicating no strong frontal features as compared with the $32.7 \mathrm{~km}$ transect. 


\section{Cruise 2-physical features and larval condition}

Satellite SST images (Fig. 7b, c) were available for 2 and 15 January 1993 (JD 2 and 15) before and after the net sampling (8 to 13 January 1993). On 2 January, a large warm (21 to $23^{\circ} \mathrm{C}$ ) filament occurred in Onslow Bay. The filament wrapped around a colder frontal eddy, which was partially obscured by cloud formation. Sampling stations were located on both sides of this frontal boundary. The next usable satellite image (Fig. 7C, 15 January) revealed that the frontal eddy had been advected downstream (northeasterly) into Raleigh Bay. A very broad frontal region with weak temperature gradients was situated in Onslow Bay. Continuous temperature and salinity data however did reveal localized frontal regimes for both transects where larvae were collected. Accordingly, any explanation of nutritional condition relative to the physical features in Onslow Bay is somewhat

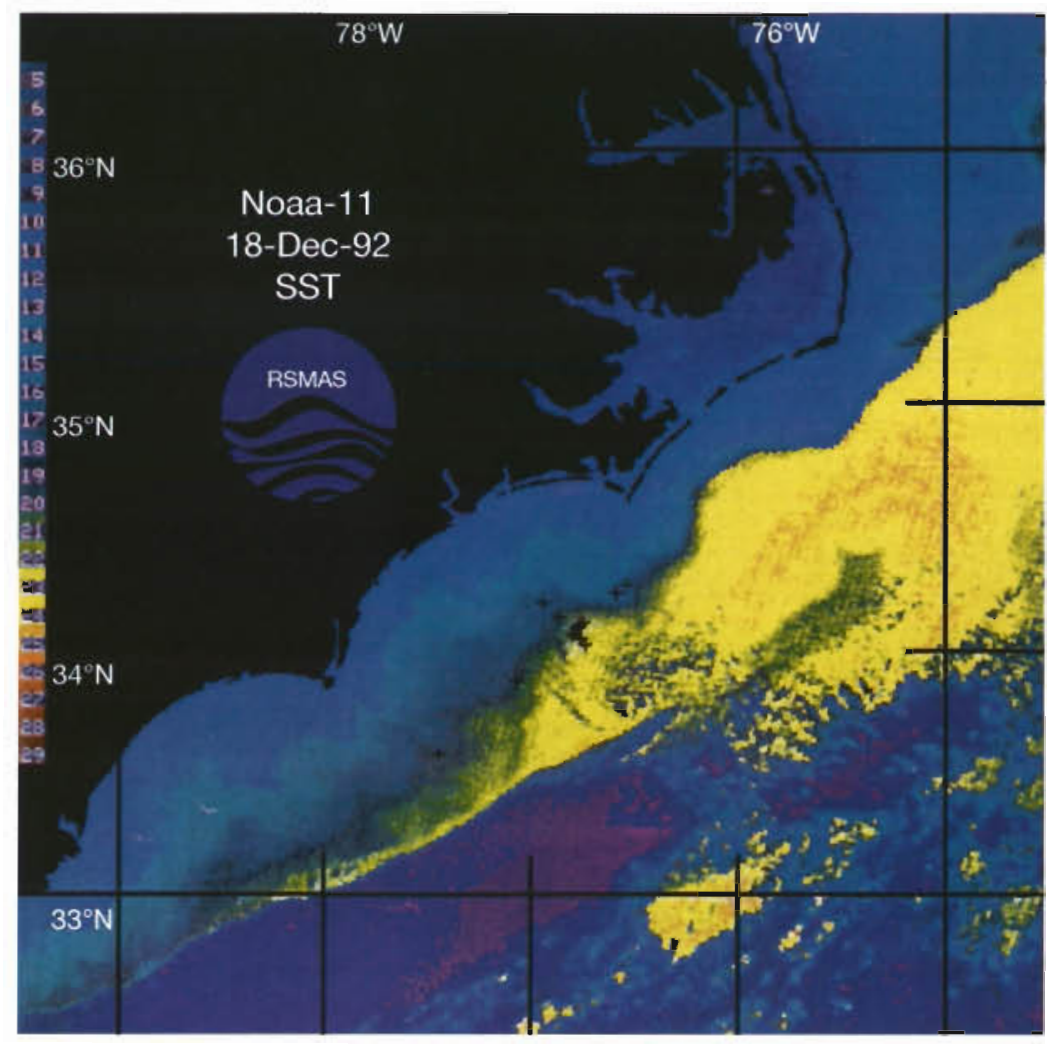

Fig. 7. (a) Satellite VHRR image December 18, 1992 during Cruise 1

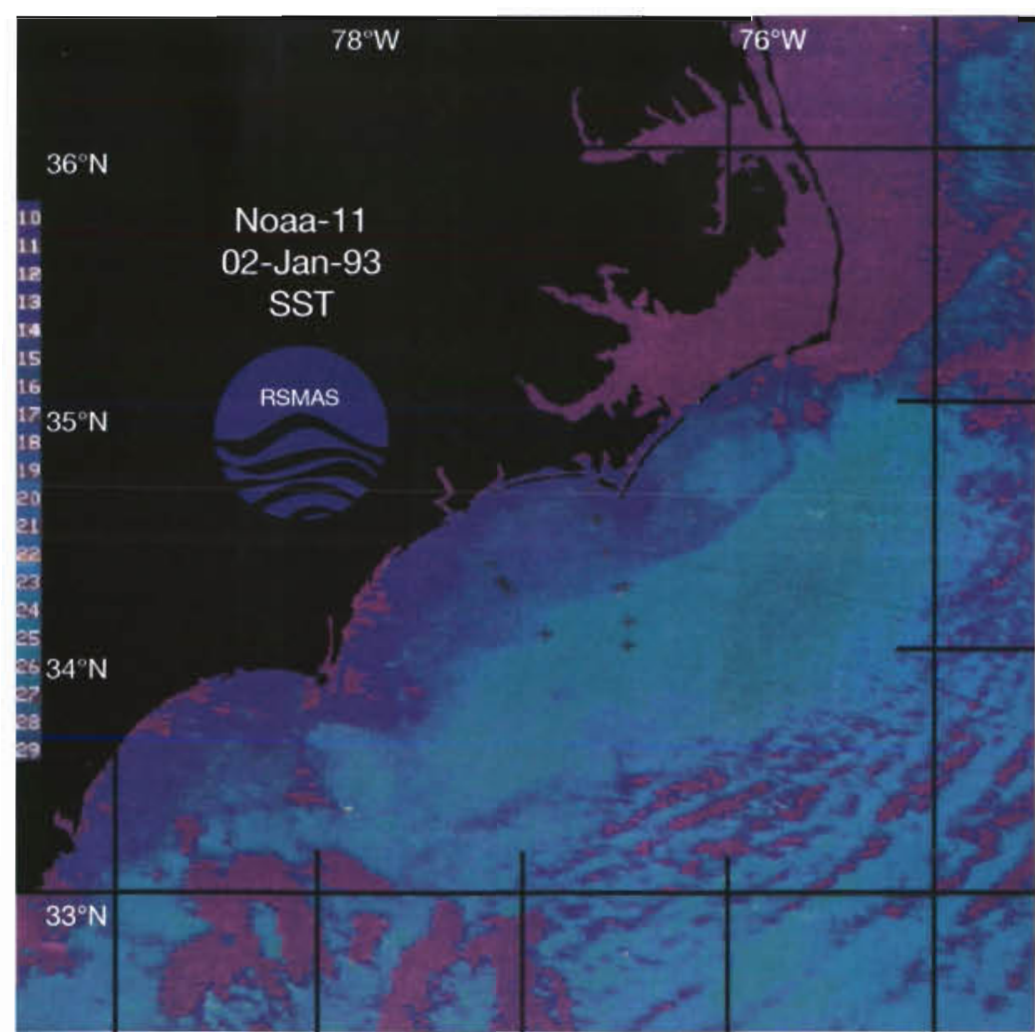

Fig. 7. (b) Satellite VHRR image January 2, 1993 during Cruise 2 inferential since only previous and following days' images are usable and the temperature profile could not provide full coverage of the sampling region.

The larvae collected during Cruise 2 consisted of 2 transects running north/ northwest-south/southeast from 8 to 13 January. The $72.6 \mathrm{~km}$ eastern transect (Figs. 4b \& 8c) consisted of 6 stations with 3 or more larvae. A highly significant difference in the distribution of the larval nutritional conditions (chisquared, $\chi^{2}=22.621, p<0.05$ ) among stations was observed. The 3 northern stations had between 77 and $100 \%$ starvation with only Stn 9308 having any non-starving larvae (23\%). These stations (9301, 9308, and 9309) were far inshore, away from any convergent frontal feature. The relatively cold water temperatures $\left(12\right.$ to $\left.15^{\circ} \mathrm{C}\right)$ at these stations suggest that they were in shelf waters, well shoreward of any front. In the front (Stns 9310, 9310.1) the percentage of 'healthy' individuals increased to $67 \%$ and there was also a relatively high proportion of 'average' 
fish just beyond the front at Stn 9312 . Stns 9310 and 9310.1 are located on the shoreward side of the front and had more healthy larvae than Stn 921.2 seaward of the front which had a higher percentage of non-healthy fish.

A second southern transect was also performed during Cruise 2 lying approximately parallel to the first transect. Seven stations provided 3 or more larvae for statistical analysis. The distribution of larval condition among the stations along the $41.1 \mathrm{~km}$ transect was highly significant (chi-squared, $\chi^{2}=$ 28.435, $\mathrm{p}<0.01$ ) although the pattern observed was more complex than on other transects. 'Healthy' larvae increased (Fig. 8d) from $0 \%$ at the northwest end to $67 \%$ in the southeast (offshore). Also with the exception of Stns 9328 and 9334, 'average' condition larvae exhibited a continuous decrease from north to south. Approximately $33 \%$ were classified as 'average' with the remainder 'starving' at northwest inshore Stn 9324, while only $7 \%$ were 'average' at the southeastern

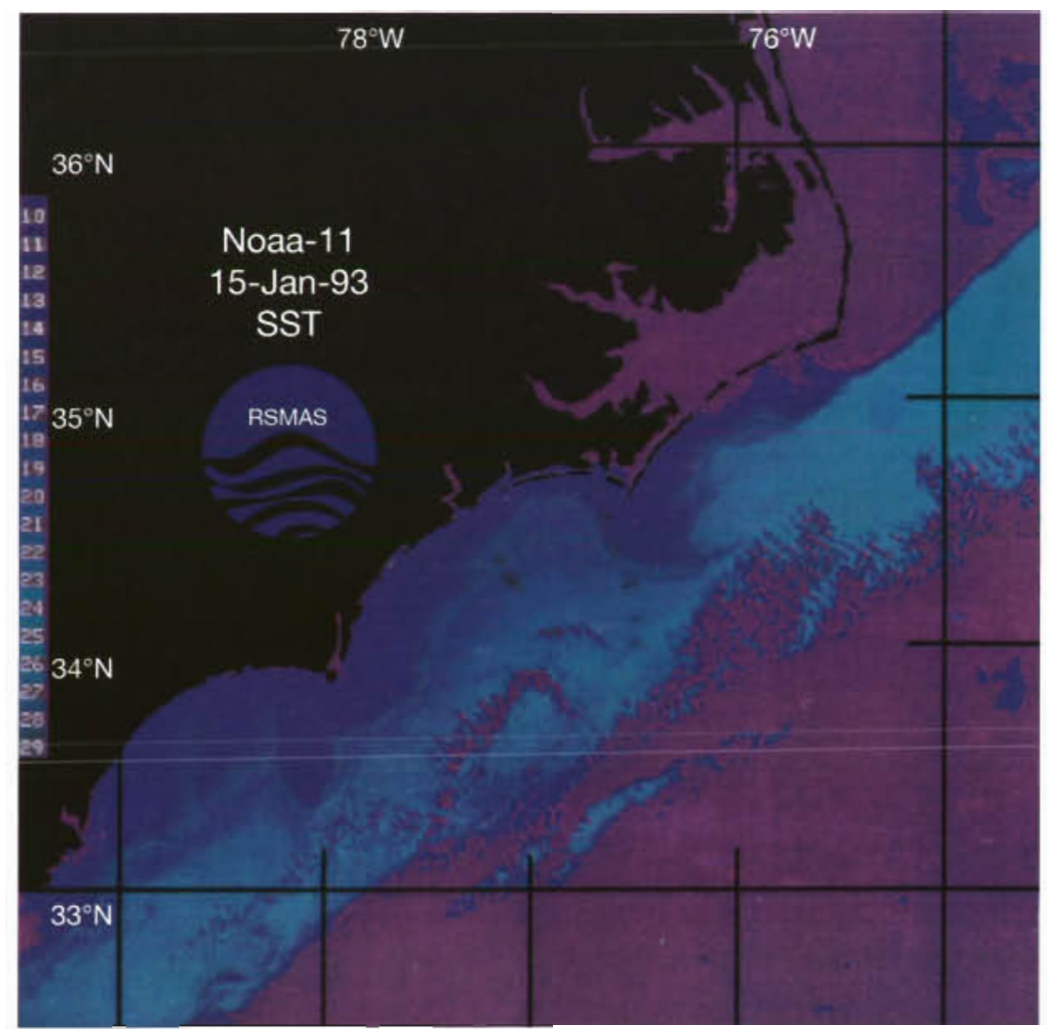

Fig. 7. (c) Satellite VHRR image January 15, 1993 during Cruise 2



Fig. 7. (d) Satellite VHRR image January 18, 1994 during Cruise 3 end of the transect (Stn 9334). The center, Stn 9328, of the transect had no 'average' larvae, but an abnormally large percentage $(87 \%)$ of 'starving' fish when viewed in relation to the transect.

Stns 9331 and 9332 were identical (approximately $65 \%$ healthy) in geographic location, and sampling differed by only approximately $15 \mathrm{~min}$. This similarity was evident in the nearly identical nutritional distributions, water temperatures and salinities. The small distance between Stn $9334 \quad$ (79\% starving) and these 2 stations indicates small-scale variability (scales of $1000 \mathrm{~s}$ of $m$ ), suggesting that this region may have been extremely close to a frontal boundary on 13 January. Stns 9331 and 9332 also had nutritional distributions similar to Stns 9310 and 9310.1 , possibly resulting from convergence associated with the same frontal feature. The inshore (nonfrontal) samples, Stns 9324 and 9327, again revealed a greater percentage of starving and non-healthy larvae. 


\section{Cruise 3-physical features and larval condition}

Satellite images during the period of Cruise 3 (January 1994) were available for the single day (Fig. 7d) when all samples were collected (18 January). No other images were available due to cloud coverage several days prior to and subsequent to our field sampling. On 18 January, a large warm $\left(19\right.$ to $\left.21^{\circ} \mathrm{C}\right)$ filament was located in Onslow Bay, extending from Cape Hatteras to east of Cape Fear. The filament was presumably separated from the axis' flow by a narrower stream of cold $\left(12\right.$ to $14^{\circ} \mathrm{C}$ ) water; however, cloud banks extending along the Gulf Stream frontal zone prevented SST data collection, and our ship track did not extend so far seaward. The western boundary of the filament produced a strong temperature front recorded in both the satellite image and surface shipboard temperature measurements. Between the western edge of this front and the cold ( 8 to $10^{\circ} \mathrm{C}$ ) inshore shelf water, the satellite image indicated a broad zone of mixed water. Salinity measurements at sampling sites revealed a minor increase from inshore to

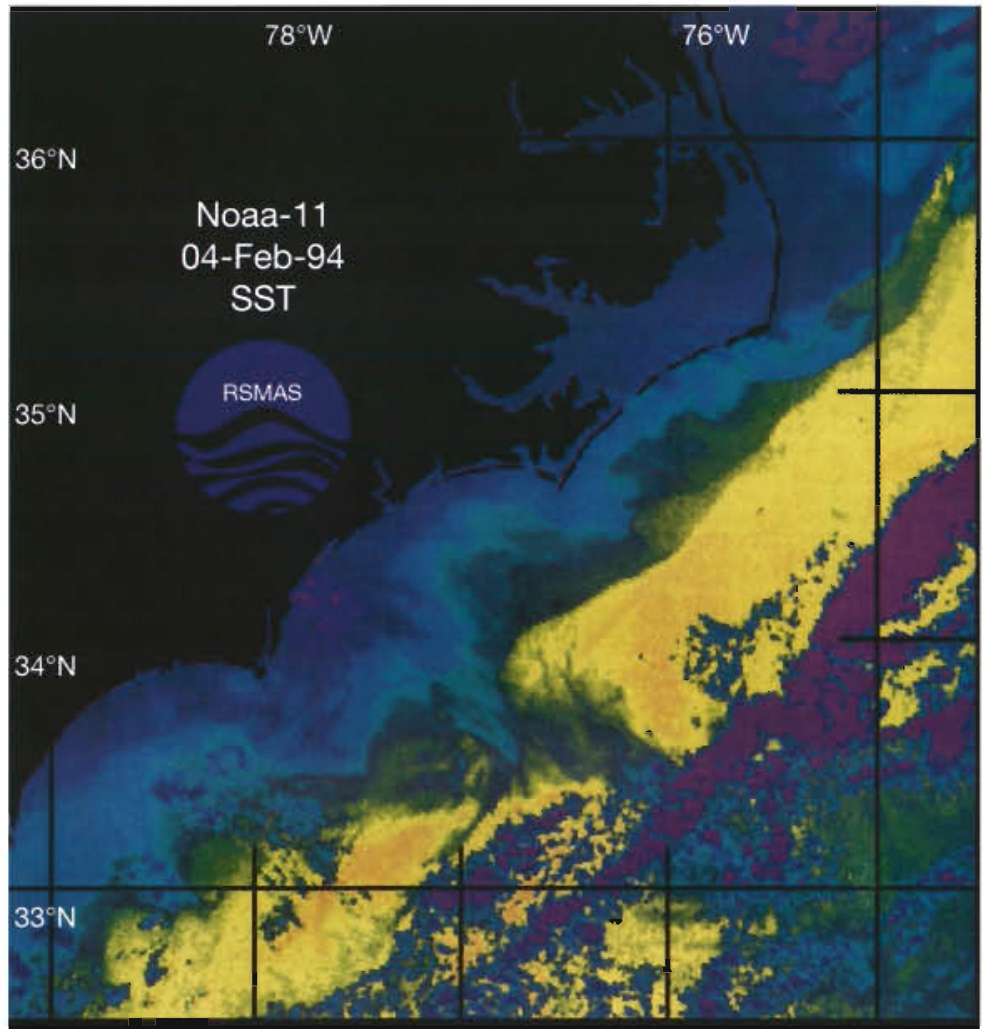

Fig. 7. (e) Satellite VHRR image February 5, 1994 during Cruise 4

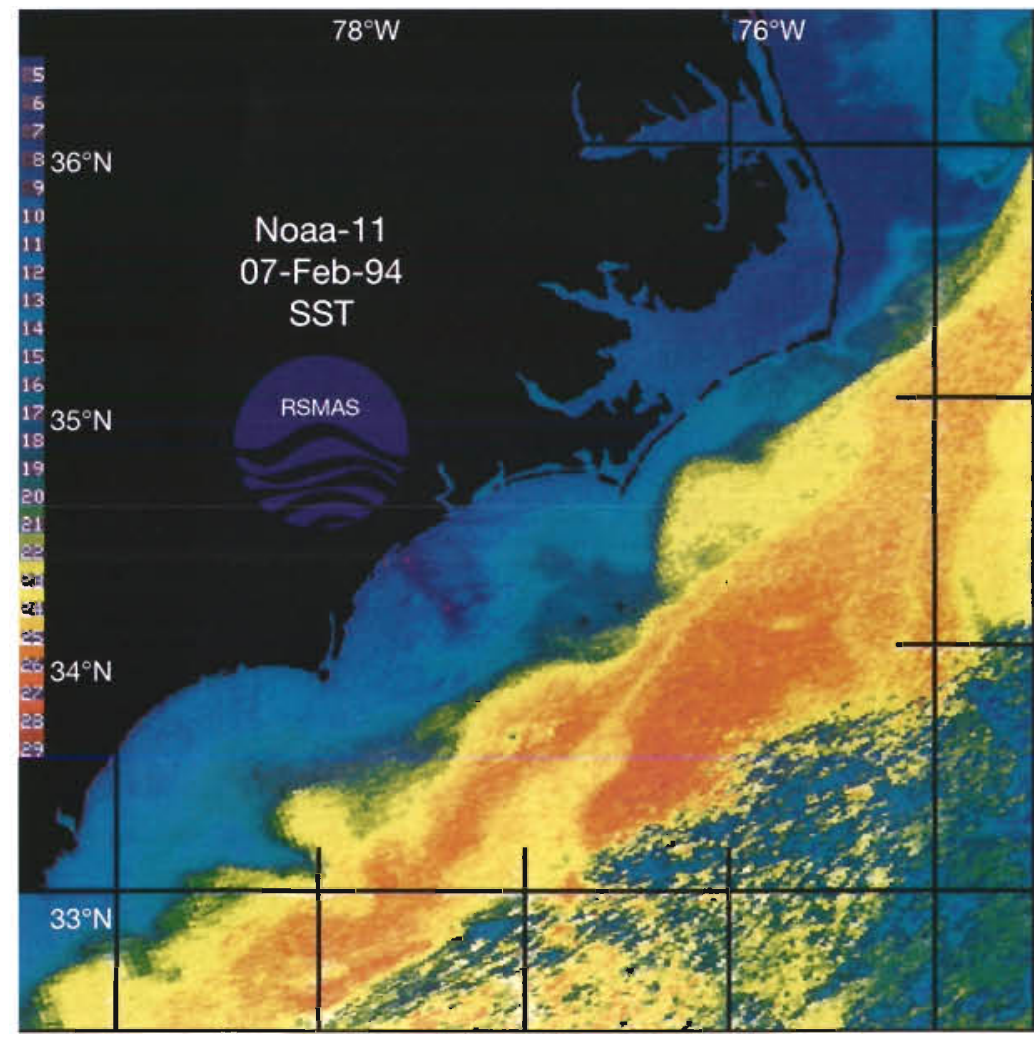

Fig. 7. (f) Satellite VHRR image February 7, 1994 during Cruise 4 offshore ( 36.11 to $36.39 \mathrm{ppt),} \mathrm{although} \mathrm{all}$ salinities were nonetheless characteristic of Gulf Stream water.

Fluorescence-based chl a measurements at sampling stations showed a slight peak inshore $\left(0.200 \mu \mathrm{g} \mathrm{l}^{-1}\right)$, presumably due to resuspension of shallow water sediments and other near-shore processes. Further offshore but west of the filament, chl a measurements were lower in the mixed waters adjacent to the front. The highest chl a measurements $\left(0.277\right.$ and $\left.0.329 \mu g ~^{-1}\right)$ were taken in the immediate vicinity of the front produced by the western edge of this filament (Stns 9412 and 9413). Further offshore in the warm core of the filament, chl a measurements dropped slightly to $0.218 \mu \mathrm{g} \mathrm{l}^{-1}$ (Stn 9415)

Condition of larvae was significantly different across the transect (chisquared, $\chi^{2}=40.192, p<0.01$ ), with fish in superior condition in the center stations of the transect, which were located just shoreward of a marked temperature front where the horizontal temperature gradient was most acute. The 2 middle 

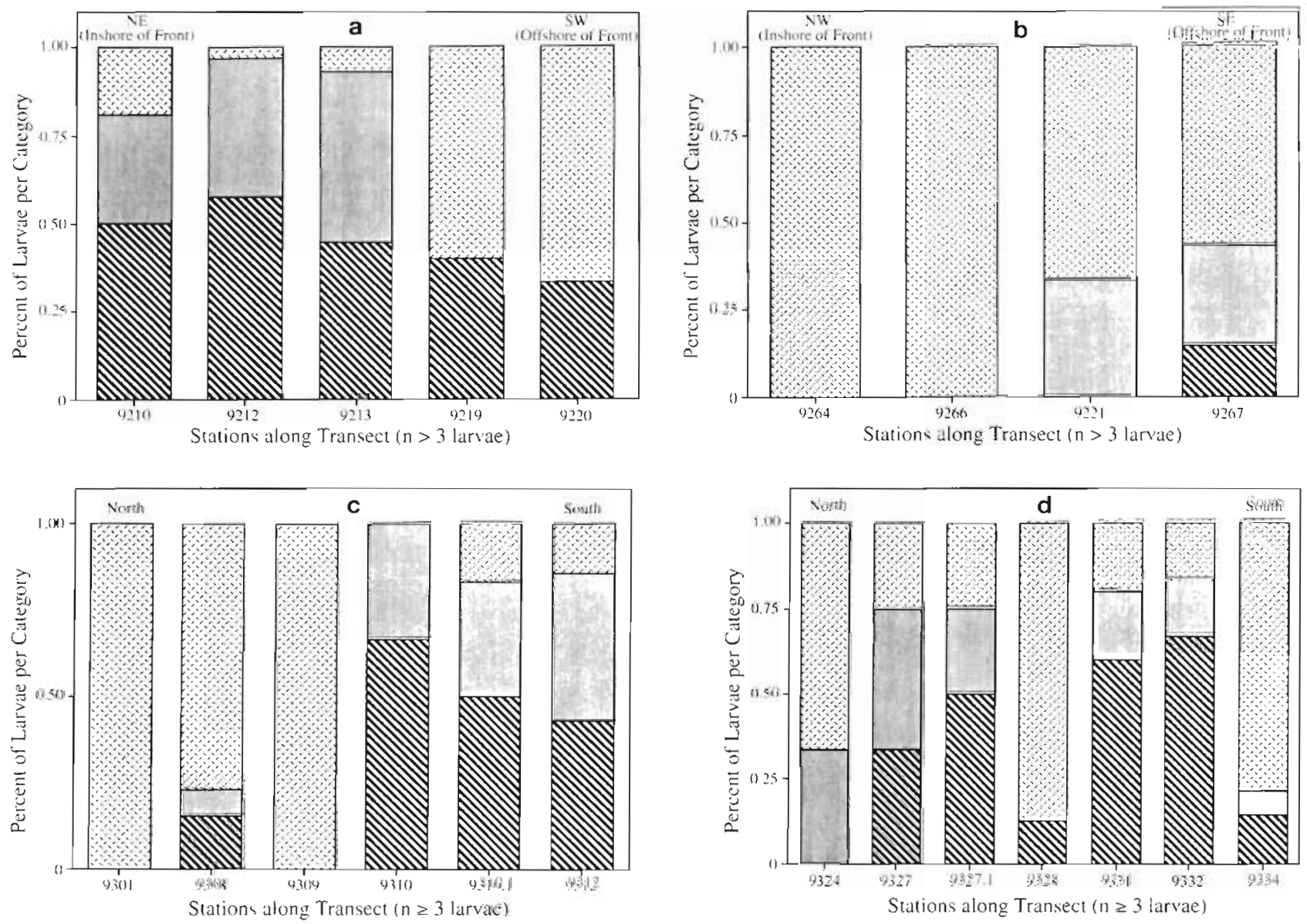

$\boldsymbol{\nabla}$ Healthy

Average

Starving

Fig. 8. Larval condition along (a) $32.7 \mathrm{~km}$. NE-SW transect of Cruise 1, (b) $26.4 \mathrm{~km}$ NW-SE transect of Cruise 1, (c) $72.6 \mathrm{~km}$ eastern N-S transect of Cruise 2, (d) $41.1 \mathrm{~km}$ western N-S transect of Cruise 2

stations, 9411 and 9412, were the only regions sampled having no 'starving' larvae collected. At these sites, 67 and $35 \%$, respectively, of the individuals were 'healthy', the remainder 'average'

The next 2 stations away from the center (9410 and 9413 ) indicated minor signs of starvation, with 23 and $21 \%$, respectively, 'starving'. Although similar in percentage starving, the non-starving larvae were distributed differently with $65 \% / 12 \%$ at Stn 9410 but $7 \% / 71 \%$ at Stn 9413 classified as 'average' and 'healthy' respectively. The endmost stations of the transect, Stn 9409 (inshore) and Stn 9414 (offshore), had the highest percentages of 'starving' larvae, 60 and $47 \%$, respectively. Stns 9409 and 9410 were well inshore of the frontal zone in mixed shelf water. A similar distribution of nutritional conditions between these 2 stations and Str 9414, located on the seaward side of the front, was observed. Only $7 \%$ were 'healthy' at Stn 9409, which was the lowest percentage along the entire transect.

\section{Cruise $4-$ physical features and larval condition}

Cruise 4 (February 1994) contained only 2 sampling sites with 15 total individuals collected. However, the nutritional condition of the larvae in these 2 sites did relate extremely closely to the prevalent physical regime. Two satellite images were available from 4 to 7 February near the sampling date (5 February) (Fig. 7e, f). These images showed the northeasterly drift of a frontal eddy. On 4 February, the offshore advection of shelf water $\left(10\right.$ to $\left.12^{\circ} \mathrm{C}\right)$ into the cyclonic circulation of this eddy centered south of Cape Lookout was clearly evident. The features depicted on 4 February presumably closely resembled those on the sampling day (5 February).

Two field stations were sampled during Cruise 4. The difference in sea surface temperature was only $1^{\circ} \mathrm{C}$, with Stn 94258 at $17.8^{\circ} \mathrm{C}$ and Stn 94259 at $18.8^{\circ} \mathrm{C}$. Neither site contained any 'healthy' larvae. Stn 94258 , located $12.4 \mathrm{~km}$ shoreward of the Gulf Stream front, 
had approximately $89 \%$ starving, while Stn 94259 (18.8 km shoreward of the front) had somewhat fewer $(83 \%)$ in a state of starvation. Both stations were located in the mixed area trailing the frontal eddy. Based on the satellite picture, the 2 stations were nowhere near a strong frontal feature.

In summary, significant variation in larval condition was observed in all samples. On 3 of 4 cruises, significant variation in condition across transects was observed, and this variation appeared to correlate with oceanographic features. Larvae appeared to be in especially good nutritional condition when near frontal features.

\section{DISCUSSION}

Larval transport is regulated by complex circulation patterns both on the continental shelf and in the vicinity of inlets. As a result of the rapid along-shore Gulf Stream influence, eddy formation may increase retention periods near these inlets, increasing an individual's vulnerability to flood tides (Pietrafesa \& Janowitz 1988). Westward Ekman transport in the South Atlantic region has also been reported (Reish et al. 1985) to show a significant relationship with recruitment, but the magnitude of this process is unclear (Myers \& Drinkwater 1989). Winter storm events may further promote cross-shelf circulation and shoreward larval drift (Checkley et al. 1988) yet also disperse aggregations of planktonic prey as indicated by decreases in otolith-based individual growth rates.

Condition is almost certainly a factor in mortality since larvae in poor condition grow slower and suffer prolonged exposure to starvation, predation, and disease. Morphological, biochemical, otolith, and histological indices are used but with some shortcomings. Morphological techniques such as body depth and dry weight are often insensitive on short time scales and must be corrected for larval shrinkage (Hjorleifsson \& Klein-MacPhee 1992). The RNA:DNA ratio also integrates growth rates over a period from $4 \mathrm{~d}$ to $1 \mathrm{wk}$ (Lough 1984). Consequently starvation effects do not become evident until 3 to $4 \mathrm{~d}$ following food deprivation. Decreases in the ratio due to temperature effects (greater protein synthesis per ribosome) are also unclear. Histological techniques suffer from time- and labor-intensive paraffin embedding, staining, and sectioning (Theilacker 1978, 1986).

Our delayed feeding experiment revealed that $\mathrm{LDH}$ activities increased greatly during the first 2 wk of larval life, in agreement with other larval studies (Kaupp 1987, and references therein). The results suggest that increased protein allocation to these pathways may be instrumental during early life ontogeny.
Both length and nutritional effects were significant on protein-specific LDH activities. Weight-specific activity of LDH declines exponentially in menhaden (Power \& Walsh 1992) in larger size-classes of larvae. Empirical and theoretical considerations of the scaling of these metabolic enzymes have been reviewed for adult (Somero \& Childress 1985, Childress \& Somero 1990) and larval fish including Reynolds number transitions (Kaupp 1987).

This study is the first reported analysis of enzyme activities in larval Atlantic menhaden obtained from field surveys. It indicates that starvation effects are evident in approximately 26 to $85 \%$ of larval Atlantic menhaden caught at sea. However, certain sampling stations did contain nearly $80 \%$ non-starving larvae, suggesting that microenvironments conducive to larval survival exist. With the exception of Cruise 4 , which provided few samples, a consistent 25 to $35 \%$ of the larvae were classified as 'healthy', 18 to $35 \%$ were of 'average' nutritional condition, and approximately 25 to nearly $50 \%$ were 'starving' Larger scale projects (i.e. greater numbers of larvae analyzed) may support this finding that the percentage of larvae in poor nutritional condition varies tremendously from station to station, and that the upper limit of this percentage may be as high as suggested in some traditional views of larval biology.

The use of the enzymatic condition index reported here has promise in that growth rates are reflected in time scales of 18 to $36 \mathrm{~h}$ as confirmed by response to initiation of feeding, as well as lack of correlation with day versus night sampling period. The effect of temperature on the actual enzymatic rates may not be as critical as in other studies (Clarke et al. 1992, Clarke \& Walsh 1993), since egg and larval stages of Atlantic menhaden naturally tolerate highly and rapidly varying salinity (10 to $30 \mathrm{ppt}$ ) and temperature regimes (10 to $25^{\circ} \mathrm{C}$ ) (Ferraro 1980, Powell \& Phonlor 1986). Second, the laboratory calibration was done at $19^{\circ} \mathrm{C}$ which was in the center of the range of observed field values $\left(16\right.$ to $22^{\circ} \mathrm{C}$ ). Third, a $3^{\circ} \mathrm{C}$ excursion on either side of the laboratory temperature would generally alter enzyme rates by less than $30 \%$. Of the biological factors, predation is most likely not a significant source of mortality, Brevoortia tyrannus eggs and larvae appear to be too large for even large copepods (Anomalocera ornata) to ingest (Turner et al. 1985).

Shipboard assay of enzyme activity shows promise for obtaining near-realtime data. The equipment required (sonicator, microcentrifuge, and microtiter plate reader) is durable and compact, requiring only small amounts of bench space. The use of a microtiter plate reader speeds throughput. Larvae collected, for example, in a $12 \mathrm{~h}$ sampling regime could easily be assayed in the next $12 \mathrm{~h}$. 
Horizontal temperature gradients in Onslow Bay are large during winter due to the proximity of the Gulf Stream $\left(>22^{\circ} \mathrm{C}\right)$ to cold $\left(<10^{\circ} \mathrm{C}\right)$ inshore coastal waters. The heterogeneous and transient nature of the physical regime in the sampling area implies that location of spawning sites could have major effects on larval survival and growth. Wave-like meanders and eddies persist for approximately $2 \mathrm{~d}$ to $2 \mathrm{wk}$ (Lee et al. 1984) in the region. Cold core frontal eddies with weekly periodicity are important for water mass, nutrient, and larval exchange (Pietrafesa \& Janowitz 1979, Lee \& Atkinson 1983, Lee et al. 1991). The outer shelf is controlled by Gulf Stream frontal disturbances, being primarily meanders and eddies (Lee 1981, 1983), which also partially affect the midshelf. Such meanders can be characterized by sea surface temperature and salinity fluctuations. Salinity data collected during the field component of this research indicate minimal variability in sampling stations since the overall range of data collected from all cruises was only 36.11 to $36.39 \mathrm{ppt}$, in contrast with reported values down to $27 \mathrm{ppt}$ (Mathews \& Pashuk 1986) during periods of high freshwater runoff.

Throughout the sampling region within any particular cruise, with the exception of Cruise 4 which consisted of only 2 stations, spatial heterogeneity was observed in larval condition. Protein-specific LDH activity varied greatly among sampling stations and continued to reveal spatial (assumed to be at least partially nutritional) differences as was found in the laboratory experiments and other experiments in our laboratories (Clarke et al. 1992). The range of observed metabolic activities with this enzyme system was similar to the laboratory calibration. As a consequence of highly variable field conditions, the range of enzyme values collected in the field far exceeds the controlled laboratory feeding experiment.

Condition of larvae seems related to location in Onslow Bay and position relative to physical features. The Gulf Stream front occurred between approximately 34 and $77 \mathrm{~km}$ from shore during the 4 field cruises and was a significant factor in the nutritional condition of the larvae. During Cruise 1, stations closer to the front contained a lower percentage of starving individuals. Similar decreases in nutritional condition with increasing distance from the front were also evident during Cruise 3 presumably due to frontal biomass accumulations (Franks 1992). Physical effects including tidal advection, upwelling and mixing at the front have been reported to enhance larval growth in the frontal region. As confirmed by this study, these effects are not fully understood since larval fish and prey density maxima are frequently found coincident with the front but occasionally several $\mathrm{km}$ on either side of the frontal region (Taggart et al. 1989), giving rise to a comparatively poor nutritional environment in the immediate vicinity of the front. This occurrence as well as the lag in response of the enzymatic condition. index may be responsible for explaining the presence of only starving larvae found bordering the front in the NW-SE transect of Cruise 1 Coastal fronts (often found between offshore and coastal waters) have a significant effect (Nakata 1989) on larval transport from spawning to nursery grounds. With the development of improved condition indices such as reported in this study, position of frontal boundaries may prove instrumental in the prediction and validation of larval transport and condition. While there is no single best index of condition for all circumstances (Ferron \& Leggett 1994), laboratory and field research presented in this study mark an initial success in the use of metabolic enzyme assays for the prediction and determination of nutritional condition of wild marine larvae.

Acknowledgements. We graciously thank S. Walsh for producing the sea surface temperature satellite images, $C$. O'Brien for technical assistance in laboratory rearing, and W. Hettler for menhaden eggs. P. Ortner, T. Lee, and R. Orhun provided valuable insight and comments. This work was supported by NOAA grant NA90-RAF-0075-SEFCAR, NSF Grant OCE-9217523, and Florida Sea Grant R/LR-A-17.

\section{LITERATURE CITED}

Ahrenholz DW (1991) Menhaden: the resource, the industry, and a management history. Mar Fish Rev 53(4):1-58

Ahrenholz DW, Nelson WR, Epperly SP (1987) Population and fishery characteristics of Atlantic menhaden, Brevoortia tyrannus. Fish Bull 85:569-600

Bailey KM, Houde ED (1989) Predation on eggs and larvae of marine fishes and the recruitment problem. Adv Mar Biol $25: 1-83$

Blaxter JHS, Ehrlich KF (1974) Changes in behavior during starvation of herring and plaice larvae. In: Blaxter JHS (ed) The early life history of fish. Springer-Verlag, Berlin, p 575-588

Cetta CM, Capuzzo JM (1982) Physiological and biochemical aspects of embryonic and larval development of the winter. flounder, Pseudopleuronectes americanus. Mar Biol 71(3): 327-337

Checkley DM, Raman S, Maillet GL, Mason KM (1988) Winter storm effects on the spawning and larval drift of pelagic fish. Nature 335:346-348

Childress JJ, Somero GN (1990) Metabolic scaling: a glycolytic perspective. Am Zool 30:161-173

Clarke ME, Calvi C, Domeier M, Edmonds M, Walsh PJ (1992) Effects of nutrition and temperature on metabolic enzyme activities in larval and juvenile red drum, Sciaenops ocellatus, and lane snapper, Lutjanus synagris. Mar Biol 112:31-36

Clarke ME, Walsh PJ (1993) Effect of nutritional status on citrate synthase activity in Acartia tonsa and Temora longicornis. Limnol Oceanogr 38(2):414-418

Cushing $\mathrm{DH}$ (1983) Are fish larvae too dilute to affect the density of their food organisms? J Plankton Res 5:847-854

Davis CS, Gallager SM, Solow AR (1992) Microaggregations 
of oceanic plankton observed by towed video microscopy. Science 257:230-232

Ferraro SP (1980) Embryonic development of Atlantic menhaden, Brevoortia tyrannus, and a fish embryo age estimation method. Fish Bull 77(4):943-949

Ferron A, Leggett WC (1994) An appraisal of condition measures for marine fish larvae. Adv Mar Biol 30:217-303

Fiedler TJ (1994) The nutritional condition of larval Atlantic menhaden, Brevoortia tyrannus, in the South Atlantic Bight. Master of Science thesis, University of Miami

Fore PL, Baxter KN (1972) Diel fluctuations in the catch of larval Gulf menhaden, Brevoortia patronus, at Galveston entrance, Texas. Trans Am Fish Soc 101:729-732

Frank KT, Leggett WC (1985) Reciprocal oscillations in densities of larval fish and potential predators: a reflection of present of past predation? Can J Fish Aquat Sci 42 : 1841-1848

Franks PJS (1992) Sink or swim: accumulation of biomass at fronts. Mar Ecol Prog Ser 82:1-12

Harding D (1974) The biology of fish larvae with particular reference to the plaice (Pleuronectes platessa Linn.). In Harden Jones FR (ed) Sea fisheries research. John Wiley and Sons, New York, p 55-66

Haury LR, McGowen JA, Wiebe PH (1978) Patterns and processes in the space-scales of plankton distributions. In: Steele $\mathrm{JH}$ (ed) Spatial patterns in plankton communities. Plenum Press, New York, p 227-327

Haury LR, Wiebe PH (1982) Oceanic zooplankton and tine scale species aggregations. Deep-Sea Res 29:915-921

Hay DE (1981) Effects of capture and fixation on gut contents and body size of Pacific herring larvae. Rapp PV Reun Cons Int Explor Mer 178:395-400

Hay DE (1982) Fixation shrinkage of herring larvae: effects of salinity, formalin concentration, and other factors. Can J Fish Aquat Sci 39:1138-1143

Hjorleifsson E, Klein-MacPhee G (1992) Estimation of live standard length of winter flounder Pleuronectes americanus larvae from formalin-preserved, ethanol-preserved and frozen specimens. Mar Ecol Prog Ser 82:13-19

Hoss DE, Checkley DM, Settle LR (1989) Diurnal buoyancy changes in larval menhaden (Brevoortia tyrannus). Rapp PV Reun Cons Int Explor Mer 191:103-111

Houde ED (1987) Fish early life dynamics and recruitment variability. Am Fish Soc Symp 2:17-29

Houde ED, Schekter RC (1.980) Feeding by marine fish larvae: developmental and functional responses. Environ Biol Fish 5(4):315-334

Hunter JR (1981) Feeding ecology and predation of marine fish larvae. In: Lasker R (ed) Marine tish larvae: morphology, ecology, and relation to fishenes. Washington Sea Grant Program, Seattle, p 34-77

Hunter JR (1984) Inferences regarding predation on the early life history stages of cod and other fishes. Floed Rapp 1 $533-562$

Jennings $S$ (1991) The effects of capture, net retention and preservation upon lengths of larval and juvenile bass, Dicentrarchus labrax (L.). J Fish Biol 38:349-357

Kaupp SE (1987) The ontogenetic development of the metabolic enzymes citrate synthase and lactate dehydrogenase in the swimming muscles of larval and juvenile fishes; a scaling of locomotory power. PhD thesis, University of California, San Diego

Kaupp SE, Somero GN (1989) Empirically determined metabolic scaling in larval and juvenile marine fish. A.m Zool 29:55A

Kentouri M, Divanach P (1982) Differences and similarities in the genesis of the locomotor and trophic behavior of pre- larval stages of Sparus auratus, Diplodus vulgaris, and Diplodus sargus. Aquaculture 27(4):355-376

Laurence GC (1974) Growth and survival of haddock (Melanogrammus aeglefinus) larvae in relation to planktonic prey concentrations. J Fish Res Bd Can 31:1415-1419

Laurence GC (1977) A bioenergetic model for the analysis of feeding and survival potential of winter flounder, Pseudopleuronectes americanus, larvae during the period from hatching to metamorphosis. Fish Bull 75:529-546

Lee TN (1981) Medsurement of Gulf Stream and wind induced shelf circulation in the South A.tlantic Bight. June 1, 1981-May 31, 1982. Rosenstiel School of Marine and Atmospheric Science, University of Miami, Florida. Progress Report

Lee TN (1983) Measurement of Gulf Stream and wind induced shelf circulation in the South Atlantic Bight. June 1, 1982-May 31, 1983. Rosenstiel School of Marine and Atmospheric Science, University of Miami, Florida. Progress Report

Lee TN, Atkinson LP (1983) Low-frequency current and temperature variability from Gulf Stream frontal eddies and atmospheric forcing along the southeast U.S. outer continental shelf. J Geophys Res 88:4541-4567

Lee TN, Kourafalou V, Wang JD (1984) Circulation on the continental shelf of the southeastern United States. Part I: Subtidal response to wind and Gulf Stream forcing during the winter. J Phys Oceanogr 14 (6):1001-1012

Lee TN, Yoder JA, Atkinson LP (1991) Gulf Stream frontal eddy influence on productivity of the southeast U. S. continental shelf. J Geophys Res 96(C12):191-205

Lewis RM, Wilkens EPH (1971) Abundance of Atlantic menhaden larvae and associated species during a diel collection at Beaufort, NC. Chesapeake Sci 12:185-187

Lough RG (1984) Larval fish trophodynamics studies on Georges Bank: sampling strategy and initial results. In: Dahl E (ed) The propagation of cod Gadus morhua. An International Symposium, Institute of Marine Research, Arendal, p 395-439

Lowery MS, Roberts SJ, Somero GN (1987) Effects of starvation on the activities and localization of glycolytic enzymes in the white muscle of the barred sand bass Paralabrax nebulifer. Physiol Zool 60:538-549

Lowery MS, Somero GN (1990) Starvation effects on protein synthesis in red and white muscle of the barred sand bass, Paralabrax nebulifer. Physiol Zool 63:630-648

Lowry OH, Rosebrough NJ, Farr AL, Randall RJ (1951) Protein measurement with the Folin phenol reagent. J Biol Chem 193:265-275

Mathews TD, Pashuk O (1986) Summer and winter hydrography of the United States South Atlantic Bight 1973-1979. J Coast Res 2(3):311-336

Moon TW (1983) Metabolic reserves and enzyme activities with food deprivation in immature American eels, Anguilla rostrata. Can J Zool 61:802-811

Myers RA. Drinkwater KF (1989) Offshore Ekman transport and larval fish survival in the Northwest Atlantic. Biol Oceanogr 6(1):45-64

Nakata $H$ (1989) Transport and distribution of fish eggs and larvae in the vicinity of coastal fronts. The early life history of fish, The Third ICES Symposium, Bergen. Rapp PV Reun Cons Int Explor Mer 191:153-159

Pietrafesa L.J, Janowit/. GS (1979) A note on the identification of a Gulf Stream spin-off eddy from Eulerian data. Geophys Res Lett 6(7):549-552

Pietrafesa LJ, Janowitz GS (1988) Physical oceanographic processes affecting larval transport around and through North Carolina inlets. Am Fish Soc Symp 3:34-50 
Powell A, Phonlon G (1986) Early life history of Atlantic menhaden, Brevoortia tyrannus, and Gulf menhaden, $B$. patronus. Fish Bull 84:991--995

Power JH, Walsh PJ (1992) Metabolic scaling, buoyancy, and growth in larval Atlantic menhaden, Brevoortia tyrannus. Mar Biol 112:17-22

Reintjes JW, Keney PM (1975) Annotated bibliography on the biology of the menhadens, genus Brevoortia, 1963-1973 NOAA Tech Rep NMFS SSRF 687

Reish RL, Deriso RB, Ruppert D, Carroll RJ (1985) An investigation of the population dynamics of Atlantic menhaden (Brevoortia tyrannus). Can J Fish Aquat Sci 42(Suppl 1) $147-157$

Snith JW, Nicholson WR, Vaughan DS, Dudley DL, Hall EA (1987) Atlantic menhaden, Brevoortia tyrannus, purse seine fishery, 1972-84, with a brief discussion of age and size composition of the landings. NOAA Tech Rep NMFS 59

Somero GN, Childress JJ (1985) Scaling of oxidative and glycolytic enzyme activities in fish muscle. In: Gilles R (ed) Circulation, respiration, and metabolism. Springer-Verlag Berlin, p 251-262

Taggart CT, Drinkwater KF, Frank KT, McRuer J, LaRouche P (1989) Larval fish, zooplankton community structure, and physical dynamics at tidal front. The early life history of

Editorial responsibility: Otto Kinne (Editor),

Oldendorf/Luhe, Germany fish, The Third ICES Symposium, Bergen. Rapp PV Reun Cons Int Explor Mer 191:184-194

Theilacker GH (1978) Effect of starvation on the histological and morphological characteristics of jack mackerel, Trachurus symmetricus, larvae. Fish Bull 76(2):403-414

Theilacker GH (1980) Changes in body measurements of larval northern anchovy, Engraulis mordax, and other fishes due to handling and preservation. Fish Bull 78:685-692

Theilacker GH (1986) Starvation-induce mortality of young sea-caught jack mackerel, Trachurus symmetricus, determined by histological and morphological methods. Fish Bull 84:1-17

Turner JT, Tester PA, Hettler WF (1985) Zooplankton feeding ecology: a laboratory study of predation on fish eggs and larvae by the copepods Anomalocera ornata and Centropages typicus. Mar Biol 90(1):1-8

Wiebe PH (1970) Small-scale spatial distribution in oceanic zooplankton. Limnol Oceanogr 15:205-217

Yang TH. Somero GN (1993) Effects of feeding and fooddeprivation on oxygen consumption, muscle protein concentration, and activities of energy metabolism enzymes in the muscle and brain of shallow living (Scorpaena guttata) and deep living (Sebastolobus alascanus) scorpaenid fishes. J Exp Biol 181:213-232

Submitted: July 10, 1996; Accepted: August 6, 1998 Proofs received from author(s): December 4, 1998 